UDK 614.71:551.51

\title{
ASSESSMENT OF AIR POLLUTION BY DUST ACCORDING TO DATA OBTAINED FROM SNOW SURVEY ON THE BASE OF FALL AREAS RECONSTRUCTION*
}

\author{
A.F. Shcherbatov1, V.F. Raputa², V.V. Turbinskiy33, T.V. Yaroslavtseva ${ }^{3}$ \\ ${ }^{1}$ Administration of the Federal Supervision Agency for Customer Protection and Human Welfare \\ for Novosibirsk region, Russian Federation, Novosibirsk, Chelyuskintsev St., 7a, 630132 \\ ${ }^{2}$ Institute of Computing Mathematics and Mathematical Geophysics of Siberian department of the Russian \\ Academy of Sciences, Russian Federation, Novosibirsk, Academician Lavrentyev Av., 6, 630090 \\ ${ }^{3}$ Federal Budget Institution of Science "Novosibirsk Scientific Research Institute of Hygiene" \\ of the Federal Supervision Agency for Customer Protection and Human Welfare, \\ Russian Federation, Novosibirsk, Krasny Av., 52, 630091
}

\begin{abstract}
The article provides the results of field survey of snow pollution by non-organic dust near cement factory in the winter season 2012/13. On the basis of computational reconstruction of fall areas the existence of stable quantitative regularities of dust content in the snowpack in the radial direction relative to the main source has been shown. The total area of dust falling has been restored and the assessment of the dust emission into atmosphere in the observed winter season has been performed.
\end{abstract}

Key words: pollution, snowpack, cement dust, computational simulation, reconstruction.

Exposure assessment is a crucial component of health assessment. For this reason, it is important to work on the improvement of the exposure assessment quality. It requires current calculation methods to combine the calculated and instrumental data.

Suspended materials hold a prominent place in the list of major air pollutants. They can be found in most industrial, power, and car discharges in air, and serve as a simple and convenient pollution indicators. Distribution of dust in various components of the environment can visually register pollution sources and exposure area.

Assessment of the dust content in the air of cities and industrial facilities is conducted with the use of stationary and mobile observation units. However in large cities that have a complex industrial and residential infrastructure, special-temporal interpretation of the observation data is complicated due to an irregular density of the observation network. It is especially challenging to conduct the assessment of long-term area pollution, and here the use of the data of the snow cover pollution monitoring is up and coming [2].

\footnotetext{
${ }^{\circledR}$ Shcherbatov A.F., Raputa V.F., Turbinskiy V.V., Yaroslavtseva T.V., 2014

Shcherbatov Aleksandr Fedorovich - Head of Administration (e-mail: upravlenie@54.rospotrebnadzor.ru; ph.: +7 (383) 220-26-78).

Raputa Vladimir Fedotovich - Doctor of Physical and Mathematical Sciences, Leading research associate of laboratory for mathematical modeling of processes in atmosphere and hydrosphere (e-mail: raputa@sscc.ru; ph.: +7 (383) 33-06-151).

Turbinskiy Viktor Vladislavovich - MD, Associate professor, Director (e-mail: rector@ngmu.ru; ph.: +7 (383) 222-32-04).

Yaroslavtseva Tatyana Vladimirovna - Candidate of Chemical Sciences (e-mail: ngi@cn.ru; ph.: +7 (383) 343-34-01).
} 
The associated studies of the air pollution and snow pollution at the stationary units of the Hydrometeorology and Environmental Monitoring Agency in the south of Western Siberia including Novosibirsk, Kemerovo, Barnaul, and Tomsk have determined the conversion factors for the pollution level. This allows, based on the snow cover studies, conducting an estimated hygienic evaluation of the city's air basin pollution.

Geochemical studies have revealed quantitative patters of the dust fall in the locations of industrial facilities which can be tracked by analyzing the anomalies in the snow cover that deposits pollution and is easy to study using any preconfigure sample collection network [2].

Accounting for the additional rather available information about the source parameters, characteristics of the dust discharge disperse composition, and current meteorological conditions allows optimizing the system of the points of snow intake, increasing the accuracy, reconstructing the snowfall fields, assessing the aggregate dust emission in the air based on the external monitoring results [5].

Numerical reconstruction of the field of extended dust fall. When calculating the average concentration in the surface layer of the atmosphere, common weather conditions have a determining value. These include the so-called normal weather conditions, which applies to power approximation of the wind speed and the coefficient of vertical turbulent exchange [1]. Using these approximations, the asymptotics of the semi-empirical equation of turbulent diffusion and the properties of the statistical characteristics of distribution of the wind speed and vertical turbulent exchange in the surface layer of the atmosphere allows us to express the density of deposition polydisperse particles over a long period of time in the form of the following regressional dependence [5]

$$
\begin{gathered}
\bar{\sigma}(r, \varphi, \vec{\theta})=\theta_{1} G\left(r, \theta_{2}, \theta_{3}\right) P\left(\varphi+180^{\circ}\right),(1) \\
G\left(r, \theta_{2}, \theta_{3}\right)= \\
=\frac{1}{r^{1.5}} \exp \left(-\frac{c}{r}\right) \int_{0}^{\infty} \frac{\omega^{\theta_{2}} \exp \left(-\theta_{3} \omega\right)}{\Gamma(1+\omega)}\left(\frac{c}{r}\right)^{\omega} d \omega,
\end{gathered}
$$

where $r, \varphi$ - are polar coordinaties, $P(\varphi)$ - surface wind pattern; $\Gamma(m)$ - Euler gammafunction, $c$ - a constant that depends on the hieght of the light, $\theta_{1}, \theta_{2}, \theta_{3}$ - unknown parameters determined based on the observation data.

Note 1. For the dust that is substantially non-uniform in terms of the distribution of its particles, its main falls in the near of the source will be presented to the larger particles, particles with settling velocity in the atmosphere, a few tens of $\mathrm{cm} / \mathrm{s}$. In this case, using the kinematic diagram of 
the transfer of particles in the atmosphere, the loss of dust in the near field can be described by a simple dependence

$$
\bar{\sigma}(r, \varphi, \vec{s})=s_{1} r^{s_{2}} \exp \left(-\frac{s_{3}}{r}\right) P\left(\varphi+180^{\circ}\right)
$$

Where unknown parameters $s_{1}, s_{2}, s_{3}$ are also measured based on the observation data.

Parameter $s_{1}$ is linearly dependent on the intensity of the source, and parameters $s_{2}, s_{3}$ depend on the characteristics of the dust particles.

The frequency of wind directions $P(\varphi)$ is usually described in a table based on 8 and 16 points. For its continuous description, it is convenient to use the following $\varphi$-angle linear interpretation between the points:

$$
\begin{gathered}
P_{i}(\varphi)=p_{i}+\frac{p_{i+1}-p_{i}}{\pi / N}\left(\varphi-\frac{\pi i}{N}\right), \\
\varphi \in\left[\frac{\pi i}{N}, \frac{\pi(i+1)}{N}\right],
\end{gathered}
$$

where $p_{i}$ is the frequency of the $i$ wind direction, $i=1, \ldots, N$.

Note 2. If a wind diagram is not available for a certain point of the area or variable dust source emission rate, the reconstruction of the deposit density field can be conducted stage-bystage.

If it is fixed $\varphi_{0}$ meaning on a radial sample collection route, conduct the value assessment $\overline{\theta_{1}}\left(\varphi_{0}\right) \equiv \theta_{1} P\left(\varphi_{0}+180^{\circ}\right), \theta_{2}, \theta_{3}$. Then, taking into account that the parameters $\theta_{2}, \theta_{3}$ virtually do not depend on $\varphi$, assess the values $\bar{\theta}_{1}(\varphi)$ for other $\varphi$ angles.

The methods of assessment of the aggregate dust deposit in the source area. One of the main characteristics of the source is pollutant emission per a specific period of time. If the field of dust deposit is quantitively reconstructed based on the observation data, for example, using dependency (1), then we have an opportunity to assess the total dust emission based on the following ratio:

$$
Q_{\text {сум }}=\iint_{S} \bar{\sigma}(\xi, \eta) d \xi d \eta
$$

where $S$ area around the source where the dust is falling, $\bar{\sigma}(\xi, \eta)$ is the density of the dust deposit presented in the orthogonal coordinates.

If area $S$ is circular in relation to the source, then with the account for (1) and note 2 , the ratio (4) can be presented in a more convenient form: 


$$
Q_{c y M}=\int_{0}^{2 \pi} \overline{\theta_{1}}(\varphi) d \varphi \cdot \int_{R_{1}}^{R_{2}} G\left(r, \theta_{2}, \theta_{3}\right) r d r .
$$

Ratio (5) simplifies the calculation of the total dust deposit in various areas and optimizes the number of sample collection points. For example, with the account for the interpolational formula (3) in the event of an 8-point establishment of the parts of the world and without the use of a wind rose, the value assessment $Q_{\text {сум }}$ can be conducted using 10 reference observation points.

\section{The study of the dust pollution of the snow cover from Iskitim cement plant in} Novosibirsk region. Cement production is accompanied by emissions into the air consisting of solid and gaseous pollutions that carry a significant risk to public health [3]. The composition of the emissions is made up of, mainly, inorganic dust, nitrogen oxides, sulfur, carbon, and benz(a)pyrene.

Iskitim is located in the south-eastern part of Novosibirsk region, $55 \mathrm{~km}$ from the regional capital - Novosibirsk. Iskitim cement plant is situated in the north of the city, in one location. In the north and the east, the facility is adjacent to the Berd River. In the south and the west of the facility, there is a residential area. The closest residential neighborhood is $30-50 \mathrm{~m}$.

Materials and methods. The study subjects include emissions from the stationary sources of Iskitimcement, the snow cover in Iskitim and outside the city limits. The study materials include Iskitimcement reports on emissions into the atmosphere of pollutants by the stationary sources in 2012 and 2013, the results of visual observations and physic-chemical analysis of the snow water samples. The sample collection routes were located in 8 points relative to the main sources of inorganic dust emissions - two close 80-meter pipes. The observation points were located over a range of 0.4-3 km.

Snow samples were collected using a plastic pipe $10 \mathrm{~cm}$ in diameter. In each of the collection points, 2 to 10 core-samples were cut out. The snow samples thawed at room temperature, and the meltwater was put through a filter (blue ribbon), and then $\mathrm{pH}$-level was measured. Within $1.5 \mathrm{~km}$ from the main sources, the $\mathrm{pH}$-values varied from 9 to 12 . The study of the chemical composition of the snow water and the separated deposit was conducted in certified laboratories of the Novosibirsk Hygiene Research Institute, the Institute of Inorganic Chemistry at the Siberian Branch of the Russian Academy of Sciences. Statistical processing and mathematical modelling were conducted at the Institute of Computational Mathematics and Mathematical Geophysics of the Siberian Branch of the Russian Academy of Sciences.

Results and discussion. Snow sampling was carried out on the 8 radial routes and at more than 40 points of the terrain. It is possible to carry out a detailed numerical analysis of the processes 
of the dust fall from the main sources of the enterprise, to establish quantitative laws of the sediment in snow in various areas. Fig. 1-3 shows the results of a numerical reconstruction based on the observation of the inorganic dust sediment density field.

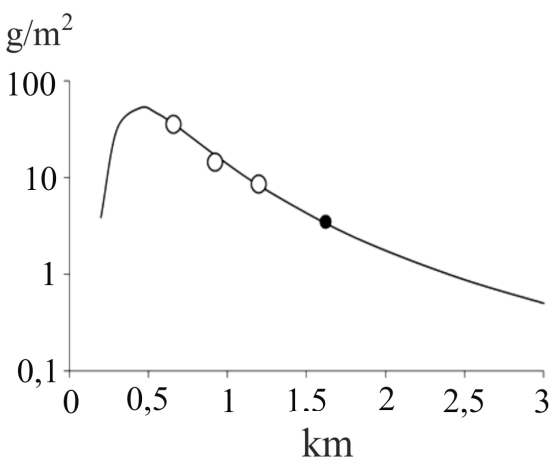

$a$

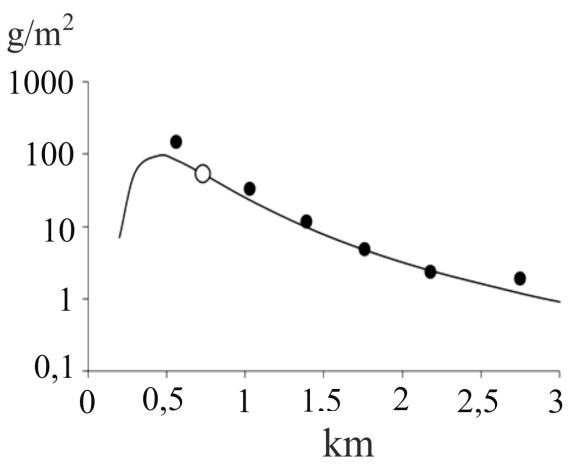

$b$

Figure 1. Reconstructed, based on dependency (1), inorganic dust deposits north-east $(a)$ and north $(b)$ of the cement plant; $\odot, \bullet-$ reference and control measurement points

Fig. 1 shows that the agreement of the calculations with the observations at the control points is quite satisfactory. The maximum deposit of inorganic dust is about 450 meters from the main sources, which indicates quite ha heterogeneous disperse composition of the settling particles. Dust loss in winter in the north-west direction is dominant and is caused, apparently, by the orographic terrain features.

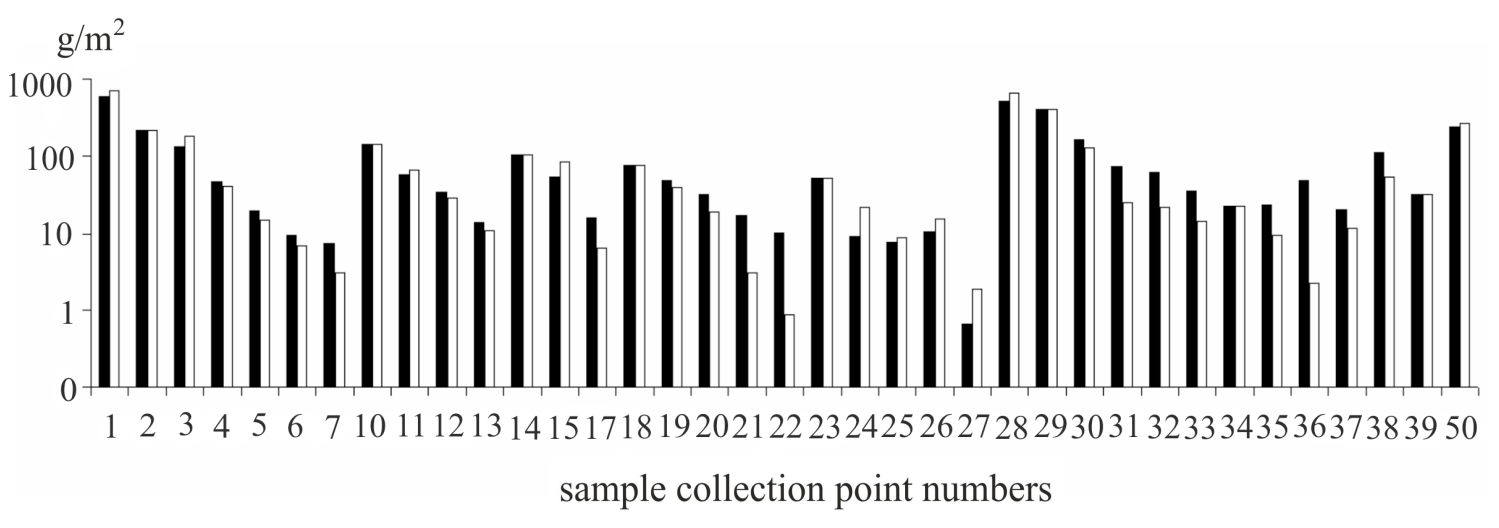

Figure 2. Measured ( $\square$ ) and reconstructed ( $\square)$, based on dependency (1), inorganic dust $\left(\mathrm{g} / \mathrm{m}^{2}\right)$ at snow sample collection points

The resulting patterns for the considered winter period made it possible to determine the value of the total loss of inorganic dust emissions at different distances from the cement plant. The content of inorganic dust in the snow within $1 \mathrm{~km}$ from the main sources of emissions "Iskitimcement" totaled 626 tons, within $2 \mathrm{~km}-875$ tons, within $3 \mathrm{~km}-942$ tons, within $4 \mathrm{~km}$ - 
969 tons. The resulting estimates of the total deposit is substantially different from the inventory data of the total dust emission of a cement plant, conducted in 2012, According to these data, the total dust emission had to total in the winter of 2012/2013 about 100 tons.



Figure 3. Reconstructed area of the inorganic dust deposit density $\left(\mathrm{g} / \mathrm{m}^{2}\right)$ around the Iskitim cement plant based on the snow course survey at the end of winter 2012/2013

Conclusions. Thus, the discrepancy between the calculated inventory data with the actual results of the field studies highlights the need to establish specific values of inorganic dust emission for each cement plant.

\section{References}

1. Berljand M.E. Sovremennye problemy atmosfernoj diffuzii i zagrjaznenija atmosfery [Modern problems of atmospheric diffusion and air pollution]. Leningrad: Gidrometeoizdat, 1975. 448 p.

2. Vasilenko V.N., Nazarov I.M., Fridman Sh.D. Monitoring zagrjaznenija snezhnogo pokrova [Monitoring of snow cover pollution]. Leningrad: Gidrometeoizdat, 1985. 182 p.

3. Turbinskij V.V., Kriga A.S., Erofeev Ju.V., Novikova I.I., Miheev V.N. Metodicheskie podhody razrabotki upravlencheskih reshenij po snizheniju riska zdorov'ju naselenija ot zagrjaznenija okruzhajushhej sredy [Methodological approaches to the development of management decisions to reduce the risk to human health from environmental pollution]. Zdorov'e naselenija i sreda obitanija, 2010, no. 7, pp. 18-21.

4. Raputa V.F., Kokovkin V.V., Devjatova A.Ju. Sravnitel'naja ocenka sostojanija 
dlitel'nogo zagrjaznenija atmosfery i snegovogo pokrova g. Novosibirska na seti stacionarnyh postov Gidrometeosluzhby [Comparative assessment of long-term contamination of atmosphere and snow cover in Novosibirsk on the network of Hydrometeorological stationary posts]. Optika atmosfery i okeana, 2010, vol. 23, no. 6, pp. 499-504.

5. Raputa V.F., Kokovkin V.V., Morozov S.V. Jeksperimental'nye issledovanija i chislennyj analiz processov zagrjaznenija snegovogo pokrova $\mathrm{v}$ okrestnostjah krupnoj avtomagistrali g. Novosibirska [Experimental research and numerical analysis of processes of snow cover pollution in the vicinity of the major highway in Novosibirsk]. Himija $v$ interesah ustojchivogo razvitija, 2010, vol. 18, no. 1, pp. 63-70. 